\title{
LICEA PARASITICA (MYXOMYCETES) NEW TO BELARUS
}

\section{Andrei Tsurykau}

F. Skorina Gomel State University, Department of Biology, Sovetskaja Str. 104, Gomel BY-246019, Belarus Samara National Research University, Institute of Natural Sciences, Department of Ecology, Botany and Nature Protection, Moskovskoye shosse 34, Samara RU-443086, Russia

E-mail: tsurykau@gmail.com

\begin{abstract}
Tsurykau A., 2017: Licea parasitica (Myxomycetes) new to Belarus [Licea parasitica (Myxomycetes) - nauja rūšis Baltarusijoje]. - Bot. Lith., 23(1): 63-64.

Licea parasitica (Zukal) G.W.Martin is reported new to Belarus. It was recorded in two localities, growing on both tree bark and epiphytic lichens in young Scots pine plantations in Gomel region, the south-eastern Belarus.
\end{abstract}

Keywords: Belarus, Gomel, Myxogastromycetidae, slime molds.

The knowledge about diversity and distribution of Myxomycetes in Belarus is limited. Some papers were published by Polish botanists and mycologists in the 19th century (TWARDOWSKA, 1885; BŁOŃSKI, 1888, $1889,1890)$ and at the beginning of the 20th century (Kastory, 1912; JAROCKI, 1924). During the ensuing years, the studies have been accidental, and the most recent contributions are from Moroz \& NOVOZHILOV $(1988,1994)$ and Moroz (1996). These papers comprise 139 species including literature investigation and own reports. This survey of literature reveals that only four species of Licea have been reported from Belarus so far, namely $L$. castanea G.Lister, $L$. minima Fr., L. operculata (Wingate) G.W.Martin and L. variabilis Schrad. (TwardowsKa, 1885; Moroz \& Novozhilov, 1994).

\section{The species and specimen characteristics}

Licea parasitica (Zukal) G.W.Martin, Mycologia 34: 702 (1942).

Our samples have sessile sporangia, scattered to gregarious, globose to subglobose, sometimes urn-shaped, brown to dark brown, up to $0.2 \mathrm{~mm}$ in diameter; spores brown, subglobose, thick-walled, smooth, $12.5-14.5 \mu \mathrm{m}$ in diameter. Plasmodium was not observed. The sessile, globose or urn-shaped sporangium with an orbicular lid close to the upper part is a distinct character of this species (Liu \& Chang, 2010).

Licea parasitica is widely distributed in Europe, Asia, North America and Australia (Martin \& Alexopoulos, 1969; Lakhanpal \& Chopra, 1982; Mitchell, 1995; Liu \& Chang, 2010). According to STEPHENSON (2003), in temperate regions L. parasiti$c a$ often appears on bark and co-occurring epiphytic bryophytes and lichens placed in moist chamber cultures, but fruiting bodies of this species require a longer time to develop than in the other species of $L i$ cea. In Belarus, L. parasitica was found in rather dry conditions in young Pinus sylvestris L. plantations growing on both tree bark and epiphytic lichens. The fruiting bodies were found in field, no moist-chamber cultures were applied.

Specimens examined: Belarus, Gomel region, Gomel district, Staro-Djatlovičskoe forest, $3 \mathrm{~km} \mathrm{SW}$ of Starye Djatloviči village, $52^{\circ} 12^{\prime} \mathrm{N} / 30^{\circ} 50^{\prime} \mathrm{E}$, on bark of pine and thallus of Parmelia sulcata, 31 July 2013, A. Tsurykau (GSU 2117); Loyew district, Karpovka forest, $1.3 \mathrm{~km} \mathrm{~N}$ of Kawpen village, 51 ${ }^{\circ} 57^{\prime}$ $\mathrm{N} / 30^{\circ} 39^{\prime} \mathrm{E}$, on bark of pine and thallus of Mica- 
rea nitschkeana, 9 Aug. 2011, A. Tsurykau (GSU 2163).

\section{ACKNOWLEDGEMENTS}

I thank Jurga Motiejūnaite (Vilnius) for species identification, Wolfgang von Brackel (Hemhofen) for valuable improvements and linguistic assistance, and an anonymous reviewer for the constructive comments, suggestions and questions.

\section{REFERENCES}

BŁoŃSKi F., 1888: Spis roślin skrytokwiatowych zebranych w r. 1887 w Puszczy Białowieskiéj. Pamiętnik Fizyjograficzny, 8: 75-119.

BŁoŃSKI F., 1889: Spis roślin zarodnikowych zebranych lub zanotowanych w lecie w r. 1888 w puszczach: Białowieskiéj, Świsłockiéj i Ladzkiéj. Pamiętnik Fizyjograficzny, 9: 63-101.

BŁoŃSKi F., 1890: Wyniki poszukiwań florystycznych skrytokwiatowych dokonanych w ciągu lata 1889 w obrębie pięciu powiatów Królestwa Polskiego. - Pamiętnik Fizyjograficzny, 10: 129-190.

JAROCKI J., 1924: Śluzowce Puszczy Białowieskiej. Część 1. Śluzowce z Rezerwatu Północnego. Acta Societatis Botanicorum Poloniae, 2: 183199.

Kastory A., 1912: Materyały do mykologii Białej
Rusi: na podstawie zbioru B. Namysłowskiego. Sprawozdanie Komisyi Fizyograficznej, 46: 101110.

Lakhanpal T.N., Chopra R.K., 1982: Taxonomic studies of Indian Myxomycetes. XX. The corticolous Myxomycetes. 1. - Sydowia, 35: 127131.

Liu C.-H., Chang J.-H., 2010: The genus Licea (Myxomycetes) in Taiwan. - Collection and Research, 23: 21-30.

Martin G.W., Alexopoulos C.J., 1969: The Myxomycetes. - Iowa City.

Mitchell D.W., 1995: The Myxomycota of Australia. - Nova Hedwigia, 60: 269-295.

Moroz E.L., 1996: Miksomicety Belorusskogo Poozer'ja. - In: Dorofeev A.M. (ed.), Soxranenie biologičeskogo raznoobrazija Belorusskogo Poozer'ja: 145-146. - Vitebsk.

Moroz E.L., Novozhilov J.K., 1988: Obzor Miksomicetov (Myxomycetes) Belorussii. - Novosti Sistematiki Nizšyx Rastenij, 25: 92-97.

Moroz E.L., Novozhilov J.K., 1994: Novye i redkie vidy Miksomicetov (Myxomycetes) Belorussii. Mikologija i Fitopatologija, 28: 21-26.

STEPHENSON S.L., 2003: Myxomycetes of New Zealand. - Hong Kong.

Twardowska M., 1885: Wiadomość o śluzowcach znalezionych w latach 1878-1883. - Pamiętnik Fizyjograficzny, 5: 160-163.

\section{LICEA PARASITICA (MYXOMYCETES) - NAUJA RŪŠIS BALTARUSIJOJE}

\section{Andrei Tsurykau}

\section{Santrauka}

Licea parasitica (Zukal) G.W. Martin yra nauja rūšis Baltarusijos miksobiotai. Ji buvo aptikta dviejose radvietėse šalies pietryčiuose, Gomelio srityje.
L. parasitica augo paprastosios pušies jaunuolyne ant medžių žievès ir ant epifitinių kerpių gniužulų. 